\title{
Application of fractional factorial design to improve hot smoked Nile Perch (Lates niloticus) quality
}

\author{
${ }^{1}$ Sokamté, T.A., ${ }^{2 *}$ Mbougueng, P. D., ${ }^{3}$ Tatsadjieu, N.L. and ${ }^{1}$ Mbofung, C. M. F. \\ ${ }^{1}$ National School of Agro-Industrial Sciences, Department of Food Science and Nutrition, P.O Box 455, \\ Ngaoundere, Cameroon \\ ${ }^{2}$ National School of Agro-Industrial Sciences, Department of Process Engineering, University of \\ Ngaoundere, P.O Box 455, Ngaoundere, Cameroon \\ ${ }^{3}$ University Institute of Technology, Department of Process Engineering and quality control, University of \\ Ngaoundere, P.O Box 454, Ngaoundere, Cameroon
}

\section{Article history: \\ Received: 18 May 2017 \\ Received in revised form: 9 June 2017 \\ Accepted: 10 June 2017 \\ Available Online: 16 June 2017}

\section{Keywords:}

Hot smoked Nile Perch, Hot smoking condition, Fractional factorial design, Proximate composition, Sensory evaluation

DOI:

http://doi.org/10.26656/ fr.2017.4.056

\begin{abstract}
The aim of this research was to study the parameters influencing moisture, salt and total phenol content of hot smoked Nile Perch and to compare the influence of processing conditions on its proximate composition and sensory quality. The effect on moisture, salt and total phenol content was investigated using ${ }^{2_{V I}^{7-a}}$ fractional factorial design with seven factors and two levels: $X_{1}$ for brine concentration, $X_{2}$ for brining time, $X_{3}$ for preliminary smoking-drying time, $X_{4}$ for smoking time, $X_{5}$ for hot smoking time, $X_{6}$ for smoking temperature and $\mathrm{X}_{7}$ for hot smoking temperature. A Multiple Linear Regression Analysis was performed to fit the mathematical model to the collected data and the model tested using analysis of variance (ANOVA). Results of ANOVA indicated the good accuracy and highest significance of the mathematical model. The range of total protein and lipid content was 17.96 to $34.34 \%$ and 0.87 to $4.43 \%$, respectively. The range of general acceptability of smoked Nile Perch was 4.6 to 8.2 based on 9-point hedonic scale. Based on the results obtained, including the overall acceptability, proximate composition and smoking criteria of finished product, samples produced with the following conditions: brining at $4 \%$ for $270 \mathrm{~min}$, drying at $30^{\circ} \mathrm{C}$ for $30 \mathrm{~min}$ and the smoked time/ temperature cycles following: $30^{\circ} \mathrm{C} / 120 \mathrm{~min} ; 50^{\circ} \mathrm{C} / 240 \mathrm{~min}$ and $80^{\circ} \mathrm{C} / 240 \mathrm{~min}$ was the best and most accepted. The results derived from this study indicate that the fractional factorial design is a useful screening tool for improving industrial smoking process of Nile Perch.
\end{abstract}

\section{Introduction}

Smoked fish is one of the most nutritious food due to its high content in unsaturated fatty acids, vitamins, minerals and essential amino acids (Arvanitoyannis and Kotsanopoulos, 2012). In France, smoked salmon is a highly valued ready-to-eat product and its consumption has increased considerably in the last decade (GallartJornet et al., 2007). France is the single largest market for smoked salmon in Europe with annual sales estimates at $25000-30000$ tons and a sale value growing at $4.7 \%$ per year (Rora et al., 2004). Hence, the smoked salmon industry is an important and vital sector in the Europe economy. Indeed, salmon seems to be the most investigated smoked fish but a lot of other fishes among which is the Nile Perch (Marc et al., 1998) can also be processed by this technique. The Nile perch is a large freshwater fish found extensively in the rivers and lakes of Africa. It is a very popular food not only due to its sensory attributes (firm texture and white flesh) but also to its high nutritional values. With a relatively high protein level, its flesh reveals the high content of omega3 fatty acids, which is important for cardiovascular diseases prevention (Werimo, 1996). Despite the potential that Nile Perch presents as an important source of income, the only processing technology locally applied to give it an added value is smoking, but smoking technology of this fish is not well developed (Marc et al., 1998). 
Smoking technology is one of the oldest food preservation methods, which is increasingly used nowadays to impart particular organoleptic characteristics to fishes then for fish preservation (Pszczola, 1995; Varlet et al., 2007). The fish smoking process can be divided into two basic categories: cold smoking and hot smoking. Generally, both smoking methods are done in three stages: brining, drying and smoking. The cold smoking process is referred to the smoking of the product at a temperature below $28^{\circ} \mathrm{C}$, therefore nutrients structure is preserved. In hot smoking, the product temperature may reach up to 70 $100^{\circ} \mathrm{C}$, leading to product cooking which is generally more suitable for direct consumption. However, the exposure of wet fish surface directly to high temperature is the most likely cause of sensory value and nutrient loss, and can produce a hard coating that prevents moisture from migrating to the surface for proper drying and limit the penetration of phenolic compounds which has considerable importance for the preservation and organoleptic properties of the smoked products (Kjällstrand and Petersson, 2001). This phenomenon is known as "case hardening". To avoid "case hardening", The smoking industry now applies the "progressive cooking-smoking", which uses increasing time/ temperature smoking cycles (Knockaert, 2002). Upon the type of fish and regional preferences for a particular product, the hot smoking of fish requires three, four or five steps in addition to the step of salting and drying. Each of the above steps has a different purpose and operating conditions (Rahman, 2007). According to Knockaert (2002), these steps are preliminary dryingsmoking, cooking-smoking, and heating/cooking smoking. Preliminary drying-smoking $\left(30^{\circ} \mathrm{C}\right)$ is the removal of surface moisture, leading to a protein coating (pellicle) on each piece of fish so that it accepts an even smoke deposit. The second step $\left(60^{\circ} \mathrm{C}\right)$ involves the conditions where smoke is deposited evenly on the surface of each piece to ensure good flavor, color, and surface preservation. The final smoking step, $90 / 100^{\circ} \mathrm{C}$ is required to allow the cooking and exudation of smoked fish fat. Usually, these three cycles require 8-12 h. Cycles of $4 \mathrm{~h}$ or less are possible with thin and lightly smoked products (Hilderbrand, 1992). The industrial specifications for finished smoked fish in the French market generally recommend a moisture content lower than $65 \%$ in the fish flesh (Cardinal et al., 2001). Additionally, hot smoked fish requires at least 3.5\% water phase salt (WPS) to prevents the production of toxins by some bacteria like Clostridium botulinum (Hilderbrand, 1992). However, due to differences found in consumer preferences from countries, the smoking industry must adapt their production parameters (salting time, salt level, and time/temperature smoking cycles) in order to respect the market demand depending on regional preferences and to satisfy their requirement for profit (Cardinal et al., 2004). The hot smoking fish requires skill and experience to produce a high-quality end product, because the transport mechanisms of salt, water, and deposition of smoke on the fish surface are governed by several factors involved during the smoking process, which can interact on quality and shelf-life of the finished product as well as its nutritional and sensory qualities. Thus, numerous researches has been conducted on the effects of smoking on the nutritional quality of many seafood species (Cardinal et al., 2001; Goulas and Kontominas, 2005; Cardinal et al.,2006; Aba and Ifannyi, 2013; Teklu and Lema, 2015) but no reference concerning smoked Nile Perch has been found in literature. To obtain a better understanding of the industrial process applications, it is important to use the basic concepts of research in food engineering related to modeling. A practical solution proposed to solve this problem is to use a fractional factorial design, which includes the performing of a limited number of experiments, and that has proven effective in solving many industrial problems (Montgomery, 2013). The purpose of this experimental approach is to gather the largest possible amount of information with the smallest number of experiments, including main effects (influence of primary factors) and joint effects (interactions) of several primary factors.

The aim of this work is to study the effects of seven smoking process parameters on moisture, salt and total phenol content of smoked Nile Perch, as well as the influence of different smoking conditions on its nutritional and sensory quality.

\section{Materials and methods}

\subsection{Raw material and sample preparation}

A total of 20 fresh Nile Perch (Lates niloticus) of 3.5 - $4 \mathrm{~kg}$ from both sex was purchased from Lake Mbakaou fishing site, in Adamawa Region of Cameroon, in November and December 2015. The fishes were transported in an ice box, directly to the Food Science Laboratory of the National High School of Agro-Industrial Sciences (ENSAI) in Cameroon where they were washed, cleaned, eviscerated, and manually filleted and cleaned before being subjected to brining operation. 


\subsection{Brining}

Brine was prepared in a stainless-steel container by dissolving refined $\mathrm{NaCl}$ in distilled water. The brine was vigorously stirred and stored overnight in a refrigerator for complete dissolution of the salt and temperature stabilization $\left(4^{\circ} \mathrm{C}\right)$. The fillets (about $200 \mathrm{~g}$ each trimmed manually) were immersed in brine at a ratio of $1: 10(\mathrm{w} /$ w) and kept in a refrigerator $\left(4^{\circ} \mathrm{C}\right)$ for a determined time (Figure 1). After brining, each fillet was rinsed for approximately 20 seconds in cold distilled water and placed on trays in the refrigerator for $1 \mathrm{~h}$.

\subsection{Hot smoking procedure}

The smoke equipment used for the smoking process of the fillets was a Matindex Air Conditioned (Model 74560, Lamurax Germany) with $0.5 \mathrm{~m} / \mathrm{s}$ airspeed. A generator produced smoke by pyrolysis $\left(400^{\circ} \mathrm{C}\right)$ of moistened (20\%) hardwood sawdust (Lophira alata). Brined fish fillets were put on trolley grids, and the smoking process started with pre-drying in the smoking oven for $30 \mathrm{~min}$ at $30^{\circ} \mathrm{C}$, without any smoke thereafter the fish fillets were subjected to smoking with increasing temperature in order to determine smoking time/ temperature cycles (Figure 1). The smoked fish fillets were then cooled at room temperature for $2 \mathrm{~h}$ and stored in polyethylene bag.

\subsection{Proximate analysis}

The proximal composition of smoked fish fillet was performed in triplicate using AOAC methods (AOAC, 2000). Moisture content was determined by oven drying of $5 \mathrm{~g}$ of minced smoked fish fillet at $105^{\circ} \mathrm{C}$ until constant weight. Total crude protein (Nitrogen content $\mathrm{x}$ 6.25) was determined from $1 \mathrm{~g}$ smoked sample. Total lipids were extracted from a $5 \mathrm{~g}$ sample of the minced smoked fish fillets using n-hexane as solvent. Results were expressed as $\mathrm{g} / 100 \mathrm{~g}$ of smoked sample.

\subsection{Salt and total phenol content}

Sodium chloride content in smoked fish samples was determined using Mohr's method described by Karl et al. (2002). The phenolic content in smoked fish was quantified by the Folin-Ciocalteu's phenol method using UV-visible spectrophotometer at $760 \mathrm{~nm}$ as described by Marc et al.(1998) with the following modifications: To $5.0 \mathrm{~g}$ of ground sample was added $50 \mathrm{~mL}$ of $95 \%$ ethanol and the phenolic compound extracted for $30 \mathrm{~min}$ with a magnetic stirrer and filtered into a $100 \mathrm{~mL}$ flask using Whatman paper No 1 . The same sample was subjected to a second extraction using $40 \mathrm{~mL}$ of $95 \%$ ethanol and both

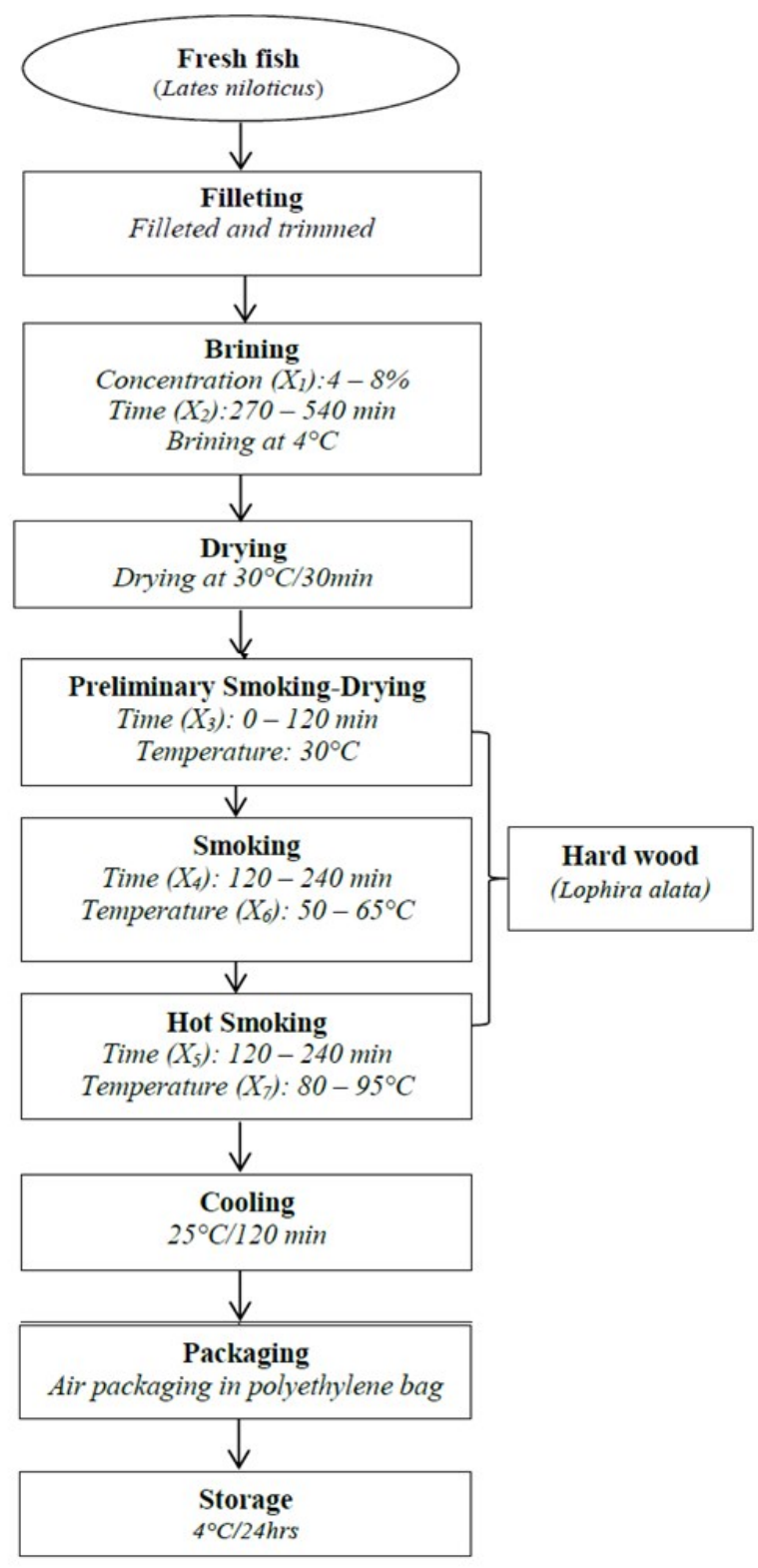

Figure 1. Flow diagram of the production of Hot Smoked Nile Perch (Lates niloticus)

extracts mixed. The total volume was adjusted to $100 \mathrm{~mL}$ using 95\% alcohol, homogenized and centrifuged at $6000 \mathrm{x} g$ for 5 minutes. $0.5 \mathrm{~mL}$ of the supernatant was added to $4.5 \mathrm{~mL}$ of distilled water and $0.5 \mathrm{~mL}$ of Folin Ciocalteu reagent $(10 \%)$ in a test tube. The mixture was incubated for 3 minutes at room temperature before adding $0.5 \mathrm{~mL}$ of $10 \%$ sodium carbonate then mixed and incubated for $40 \mathrm{~min}$ in the dark at room temperature. The absorbance was read at $760 \mathrm{~nm}$. The total phenol content was expressed as mg equivalent gallic acid $/ 100 \mathrm{~g}$ smoked fish using the standard curve of gallic acid.

\subsection{Sensory evaluation}

Organoleptic characteristics of smoked fish mainly texture, taste, odor, color, and overall acceptability was evaluated by fifteen panelists, students (both sex) of the 
Department of Food Science and Nutrition of ENSAI. Samples were removed from the refrigerator, held for 30 min at room temperature and presented randomly with different tree digit code at each panelist. The consumers expressed their degree of liking or disliking using a ninepoint hedonic scale ranging from "like extremely: 9" to "dislike extremely: 1" (Poste et al., 1991).

\subsection{Experimental design}

A two-level fractional factorial design ${ }^{2_{V I}^{7-a}}$ for 20 experiments, including 16 experiments for the $2_{V I}^{7-a}$ design (seven factors with two levels) and 4 additional replicates at the center point was used for this study. The tested factors were: $\mathrm{X}_{1}=$ brine concentration, $\mathrm{X}_{2}=$ brining time, $\mathrm{X}_{3}=$ preliminary smoking-drying time, $\mathrm{X}_{4}=$ smoking time, $\mathrm{X}_{5}=$ hot smoking time, $\mathrm{X}_{6}=$ smoking temperature and $\mathrm{X}_{7}=$ hot smoking temperature. The real and coded value of each parameter is presented in Table 1. The choice of the levels of variable was based on the preliminary experiments and on the literature.

Table 1. Factors, their coded levels and actual values as used in the design

\begin{tabular}{lcccc}
\hline Independent variables & & \multicolumn{3}{c}{ Real values of coded } \\
& Symbol & \multicolumn{3}{c}{ levels } \\
\cline { 3 - 5 } & & -1 & 0 & 1 \\
\hline Brine concentration (\%) & $\mathrm{X}_{1}$ & 4 & 6 & 8 \\
Brining time (min) & $\mathrm{X}_{2}$ & 270 & 405 & 540 \\
$\begin{array}{l}\text { Preliminary smoking- } \\
\text { drying time (min) }\end{array}$ & $\mathrm{X}_{3}$ & 0 & 60 & 120 \\
$\begin{array}{l}\text { Smoking time (min) } \\
\text { Hot smoking time (min) }\end{array}$ & $\mathrm{X}_{4}$ & 120 & 180 & 240 \\
$\begin{array}{l}\text { Smoking temperature } \\
\left({ }^{\circ} \mathrm{C}\right)\end{array}$ & $\mathrm{X}_{5}$ & 120 & 180 & 240 \\
$\begin{array}{l}\text { Hot smoking temperature } \\
\left({ }^{\circ} \mathrm{C}\right)\end{array}$ & $\mathrm{X}_{6}$ & 50 & 57.5 & 65 \\
\hline
\end{tabular}

The first-order model with interaction terms proposed for each response variable $\left(y_{\mathrm{i}}\right)$ was based on the multiple linear regression method. The empirical model in terms of coded factors was:

$$
y_{i}=\beta_{0}+\sum_{i=1}^{k} \beta_{i} x_{i}+\sum_{i<j}^{k} \sum \beta_{i j} x_{i} x_{j}+\varepsilon
$$

where $y_{i}$ is the predicted response (\% moisture, salt, and total phenol content), $x_{\mathrm{i}}$ are the coded values of the factors, $\beta_{0}$ is a constant, $\beta_{\mathrm{i}}$ is the main effect coefficients for each variable and $\beta_{i j}$ is the interaction effect coefficients between two variables, and $\varepsilon$ represent the noise, curvature or error observed in the response.

The Statistica software (version 7.0.0) was used to perform statistical analysis and response surface. The goodness of fit of the model and significance of each regression coefficient was evaluated by regression analysis and ANOVA.

\section{Results and discussion}

\subsection{Evaluation of fitted model}

Two levels were attributed to each variable as indicated in Table 1 and twenty experiments were conducted to determine how the seven variables influence moisture, salt and total phenol content of smoked Nile Perch obtained. Factorial fractional methodology is an empirical modeling technique used to evaluate the relationship between a set of controllable experimental factors and observed results. The moisture, salt and total phenol content of smoked Nile Perch from the experimental design at each experimental point are summarized and listed in Table 2. The results were analyzed using analysis of variance (ANOVA). The regression equations (1, 2 and 3 ) obtained give respectively, the moisture, salt and total phenol content of smoked Nile Perch, as a function of different variables. Table 3 (a-c) summarized the estimated effects and coefficients of each factor of the corresponding empirical model at $95 \%$ confidence level. The $p$-values were used as a tool to check the significance of each of the coefficients. The smaller the $p$-value, the more significant was the corresponding coefficient. For a $95 \%$ confidence levels, the $p$-value should be less than or equal to 0.05 for the effect to be statistically significant. Only the significant terms are included in each equation, which is valid only for coded units:

$\mathrm{Y}_{\text {Мо }}=66.020-1.324 \mathrm{X}_{1}-1.30 \mathrm{X}_{3}-1.607 \mathrm{X}_{4}-2.406 \mathrm{X}_{5}-2.333 \mathrm{X}_{6}-0.945 \mathrm{X}_{7}-1.426 \mathrm{X}_{1} \mathrm{X}_{6}$

$\mathrm{Y}_{\mathrm{Nacl}}=3.993+0.783 \mathrm{X}_{1}-0.000 \mathrm{X}_{2}+0.406 \mathrm{X}_{4}+0.347 \mathrm{X}_{5}-0.157 \mathrm{X}_{6}+0.734 \mathrm{X}_{7}-0.587 \mathrm{X}_{1} \mathrm{X}_{2}+$ $0.395 X_{1} X_{6}+1.080$

$$
\mathrm{Y}_{\mathrm{TP}}=42.266+9.700 \mathrm{X}_{6}-9.035
$$

*Factor $\mathrm{X}_{2}$ (brining time) and $\mathrm{X}_{6}$ (Smoking temperature) are not significant, however, due to their significant interactions in $\mathrm{X}_{1} \mathrm{X}_{2}$ and $\mathrm{X}_{1} \mathrm{X}_{6}$ respectively they were included in the model (2) 


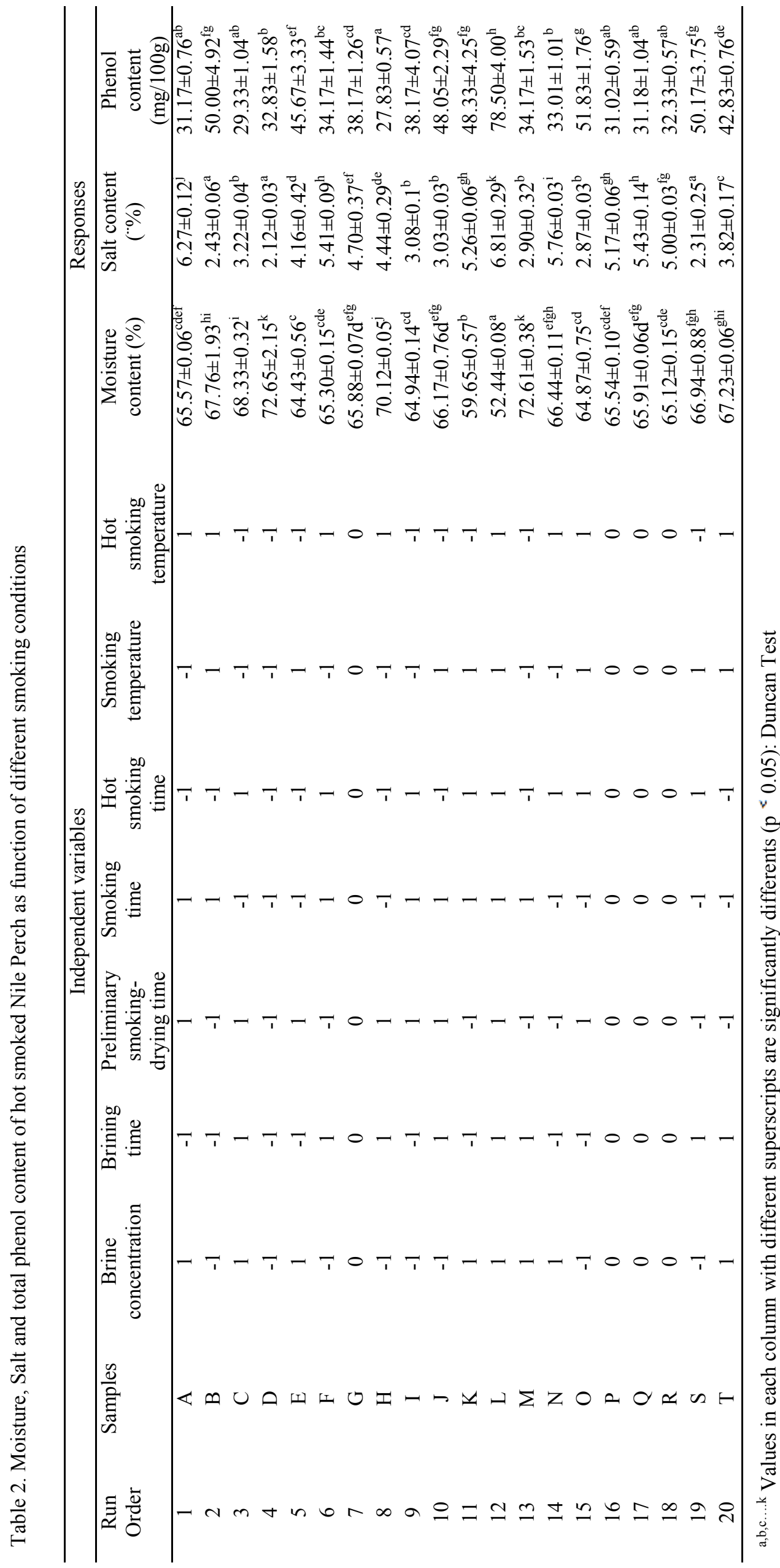


Table 3. Estimated Effect and coefficients of the empirical model for; (a) moisture content; (b) salt content; (c) phenol content

(a)

\begin{tabular}{|c|c|c|c|c|c|c|}
\hline & Effect & Std.Err. & $\mathrm{t}(8)$ & $\mathrm{p}$ & Coeff. & Std.Err. \\
\hline Mean/Interaction & 66.01954 & 0.251552 & 262.4489 & 0.000000 & 66.01954 & 0.251552 \\
\hline Curvature & -0.81798 & 1.124974 & -0.7271 & 0.487890 & -0.40899 & 0.562487 \\
\hline (1)Brine concentration & -2.64792 & 0.503104 & -5.2632 & 0.000762 & -1.32396 & 0.251552 \\
\hline $\begin{array}{l}\text { (3)Preliminary smoking- } \\
\text { drying time }\end{array}$ & -2.60371 & 0.503104 & -5.1753 & 0.000848 & -1.30185 & 0.251552 \\
\hline (4)Smoking time & -3.21312 & 0.503104 & -6.3866 & 0.000212 & -1.60656 & 0.251552 \\
\hline (5)Hot smoking time & -4.81237 & 0.503104 & -9.5654 & 0.000012 & -2.40619 & 0.251552 \\
\hline (6)Smoking temperature & -4.66610 & 0.503104 & -9.2746 & 0.000015 & -2.33305 & 0.251552 \\
\hline (7)Hot smoking temperature & -1.89002 & 0.503104 & -3.7567 & 0.005570 & -0.94501 & 0.251552 \\
\hline 1 by 3 & -0.96721 & 0.503104 & -1.9225 & 0.090767 & -0.48360 & 0.251552 \\
\hline 1 by 5 & -1.14754 & 0.503104 & -2.2809 & 0.051996 & -0.57377 & 0.251552 \\
\hline 1 by 6 & -2.85163 & 0.503104 & -5.6681 & 0.000471 & -1.42582 & 0.251552 \\
\hline 1 by 7 & -1.22555 & 0.503104 & -2.4360 & 0.040820 & -0.61277 & 0.251552 \\
\hline
\end{tabular}

(b)

\begin{tabular}{lcccccc}
\hline & Effect & Std.Err. & $\mathrm{t}(8)$ & $\mathrm{p}$ & Coeff. & Std.Err. \\
\hline Mean/Interaction & 66.01954 & 0.251552 & 262.4489 & 0.000000 & 66.01954 & 0.251552 \\
Curvature & -0.81798 & 1.124974 & -0.7271 & 0.487890 & -0.40899 & 0.562487 \\
(1)Brine concentration & -2.64792 & 0.503104 & -5.2632 & 0.000762 & -1.32396 & 0.251552 \\
$\begin{array}{l}\text { (3)Preliminary smoking- } \\
\text { drying time }\end{array}$ & -2.60371 & 0.503104 & -5.1753 & 0.000848 & -1.30185 & 0.251552 \\
(4)Smoking time & -3.21312 & 0.503104 & -6.3866 & 0.000212 & -1.60656 & 0.251552 \\
(5)Hot smoking time & -4.81237 & 0.503104 & -9.5654 & 0.000012 & -2.40619 & 0.251552 \\
(6)Smoking temperature & -4.66610 & 0.503104 & -9.2746 & 0.000015 & -2.33305 & 0.251552 \\
(7)Hot smoking temperature & -1.89002 & 0.503104 & -3.7567 & 0.005570 & -0.94501 & 0.251552 \\
1 by 3 & -0.96721 & 0.503104 & -1.9225 & 0.090767 & -0.48360 & 0.251552 \\
1 by 5 & -1.14754 & 0.503104 & -2.2809 & 0.051996 & -0.57377 & 0.251552 \\
1 by 6 & -2.85163 & 0.503104 & -5.6681 & 0.000471 & -1.42582 & 0.251552 \\
1 by 7 & -1.22555 & 0.503104 & -2.4360 & 0.040820 & -0.61277 & 0.251552 \\
\hline
\end{tabular}

(c)

\begin{tabular}{lcccccc}
\hline & Effect & Std.Err. & $\mathrm{t}(13)$ & $\mathrm{p}$ & Coeff. & Std.Err. \\
\hline Mean/Interaction & 42.2658 & 1.674544 & 25.24016 & 0.000000 & 42.26576 & 1.674544 \\
Curvature & -18.0691 & 7.488788 & -2.41282 & 0.031324 & -9.03455 & 3.744394 \\
$\begin{array}{l}\text { (3)Preliminary smoking- } \\
\text { drying time }\end{array}$ & 3.1555 & 3.349088 & 0.94220 & 0.363269 & 1.57776 & 1.674544 \\
(4)Smoking time & & & & & & \\
(5)Hot smoking time & 6.2485 & 3.349088 & 1.86574 & 0.084800 & 3.12426 & 1.674544 \\
(6)Smoking temperature & 6.3283 & 3.349088 & 1.88955 & 0.081325 & 3.16414 & 1.674544 \\
(7)Hot smoking temperature & 19.3997 & 3.349088 & 5.79254 & 0.000063 & 9.69986 & 1.674544 \\
\hline
\end{tabular}


Table 4. Analysis of variance (ANOVA) for suggested linear model of; (a) moisture content; (b) salt content; (c) phenol content

(a)

\begin{tabular}{|c|c|c|c|c|c|}
\hline & $\mathrm{SS}$ & $\mathrm{df}$ & MS & $\mathrm{F}$ & $\mathrm{p}$ \\
\hline Main effects & 290.474 & 6 & 48.4124 & 47.82 & 0.0000 \\
\hline Curvature & 0.5353 & 1 & 0.53527 & 0.52868 & 0.487890 \\
\hline (1)Brine concentration & 28.0460 & 1 & 28.04603 & 27.70104 & 0.000762 \\
\hline (3)Preliminary smoking-drying time & 27.1172 & 1 & 27.11719 & 26.78362 & 0.000848 \\
\hline (4)Smoking time & 41.2965 & 1 & 41.29647 & 40.78849 & 0.000212 \\
\hline (5)Hot smoking time & 92.6358 & 1 & 92.63581 & 91.49631 & 0.000012 \\
\hline (6)Smoking temperature & 87.0900 & 1 & 87.08996 & 86.01868 & 0.000015 \\
\hline (7)Hot smoking temperature & 14.2887 & 1 & 14.28865 & 14.11289 & 0.005570 \\
\hline 1 by 3 & 3.7420 & 1 & 3.74197 & 3.69594 & 0.090767 \\
\hline 1 by 5 & 5.2674 & 1 & 5.26741 & 5.20261 & 0.051996 \\
\hline 1 by 6 & 32.5273 & 1 & 32.52725 & 32.12714 & 0.000471 \\
\hline 1 by 7 & 6.0079 & 1 & 6.00789 & 5.93399 & 0.040820 \\
\hline Residual Error & 8.0996 & 8 & 1.01245 & & \\
\hline Lack of Fit & 7.692 & 5 & 1.5383 & 11.31 & 0.037 \\
\hline Pure Error & 0.408 & 3 & 0.1360 & & \\
\hline Total SS & 346.6535 & 19 & & & \\
\hline
\end{tabular}

$\mathrm{S}=1.00621 \quad$ PRESS $=79.9884 \quad \mathrm{R}^{2}=97.66 \%$ (prod) $-\mathrm{R}^{2}=76.93 \% \quad$ Adj- $\mathrm{R}^{2}=94.45 \%$

SS: Sum of squares; df: degree of freedom; MS: Mean square; F: F test; $\mathrm{p}$ : $p$-value

(b)

\begin{tabular}{|c|c|c|c|c|c|}
\hline & SS & $\mathrm{df}$ & MS & $\mathrm{F}$ & $\mathrm{p}$ \\
\hline Main effects & 24.2984 & 7 & 3.47120 & 18.11 & 0.000 \\
\hline Curvature & 3.73514 & 1 & 3.735139 & 19.48246 & 0.001686 \\
\hline (1)Brine concentration & 9.79843 & 1 & 9.798432 & 51.10854 & 0.000054 \\
\hline (2)Brining time & 0.00000 & 1 & 0.000002 & 0.00001 & 0.997769 \\
\hline (3)Preliminary smoking-drying time & 0.93625 & 1 & 0.936255 & 4.88350 & 0.054457 \\
\hline (4)Smoking time & 2.63726 & 1 & 2.637264 & 13.75595 & 0.004853 \\
\hline (5)Hot smoking time & 1.92230 & 1 & 1.922303 & 10.02672 & 0.011430 \\
\hline (6)Smoking temperature & 0.39382 & 1 & 0.393819 & 2.05416 & 0.185601 \\
\hline (7)Hot smoking temperature & 8.61032 & 1 & 8.610321 & 44.91137 & 0.000088 \\
\hline 1 by 2 & 5.50565 & 1 & 5.505649 & 28.71742 & 0.000457 \\
\hline 1 by 6 & 2.49814 & 1 & 2.498137 & 13.03026 & 0.005662 \\
\hline Residual Error & 1.72546 & 9 & 0.191718 & & \\
\hline Lack of Fit & 1.4423 & 6 & 0.24038 & 2.55 & 0.237 \\
\hline Pure Error & 0.2832 & 3 & 0.09439 & & \\
\hline Total SS & 37.76278 & 19 & & & \\
\hline
\end{tabular}

$\mathrm{S}=0.437856 \quad$ PRESS $=15.8907 \quad \mathrm{R}^{2}=95.43 \%$ (pred)- $\mathrm{R}^{2}=57.92 \% \quad$ Adj- $\mathrm{R}^{2}=90.35 \%$

SS: Sum of squares; df: degree of freedom; MS: Mean square; F: F test; $\mathrm{p}$ : $p$-value 
(c)

\begin{tabular}{|c|c|c|c|c|c|}
\hline & SS & $\mathrm{df}$ & MS & $\bar{F}$ & $\mathrm{p}$ \\
\hline Main effects & 1892.14 & 5 & 378.43 & 8.43 & 0.001 \\
\hline Curvature & 261.194 & 1 & 261.194 & 5.82171 & 0.031324 \\
\hline (3)Preliminary smoking-drying time & 39.829 & 1 & 39.829 & 0.88775 & 0.363269 \\
\hline (4)Smoking time & 156.176 & 1 & 156.176 & 3.48098 & 0.084800 \\
\hline (5)Hot smoking time & 160.188 & 1 & 160.188 & 3.57040 & 0.081325 \\
\hline (6)Smoking temperature & 1505.398 & 1 & 1505.398 & 33.55354 & 0.000063 \\
\hline (7)Hot smoking temperature & 30.547 & 1 & 30.547 & 0.68086 & 0.424173 \\
\hline Residual Error & 583.252 & 13 & 44.866 & & \\
\hline Lack of Fit & 549.01 & 10 & 54.90 & 4.81 & 0.111 \\
\hline Pure Error & 32.24 & 3 & 11.41 & & \\
\hline Total SS & 2736.585 & 19 & & & \\
\hline
\end{tabular}

$\mathrm{S}=6.69818 \quad$ PRESS $=1815.90 \quad \mathrm{R}^{2}=78.69 \%$ (pred)- $\mathrm{R}^{2}=33.64 \% \quad$ Adj- $\mathrm{R}^{2}=68.85 \%$

SS: Sum of squares; df: degree of freedom; MS: Mean square; F: F test; $\mathrm{p}$ : $p$-value

Where $\mathrm{Y}_{\mathrm{Mo}}, \mathrm{Y}_{\mathrm{NaCl}}$ and $\mathrm{Y}_{\mathrm{TP}}$ are the responses of moisture, salt and total phenol content, respectively, and $X_{1}, X_{2}$, $\mathrm{X}_{3}, \mathrm{X}_{4}, \mathrm{X}_{5}, \mathrm{X}_{6}$ and $\mathrm{X}_{7}$ are the coded values of the test variables $X_{1}=$ brine concentration, $X_{2}=$ brining time, $X_{3}$ $=$ preliminary smoking-drying time, $\mathrm{X}_{4}=$ smoking time, $\mathrm{X}_{5}=$ hot smoking time, $\mathrm{X}_{6}=$ smoking temperature and $\mathrm{X}_{7}=$ hot smoking temperature, respectively.

The goodness of fit of these mathematical models was checked by criteria at $95 \%$ confidence level. These criteria include the coefficient of determination $\left(\mathrm{R}^{2}\right)$, adjusted- $\mathrm{R}^{2}$ and predicted- $\mathrm{R}^{2}$. The corresponding analysis of variance (ANOVA) of each model is presented in Table 4 (a-c). The coefficient of determination $\left(\mathrm{R}^{2}\right)$ measures the proportion of total variability explained by the model. It is suggested that for a good fit model $\mathrm{R}^{2}$ should be close to 1 and should be at least 0.8 . A value greater than 0.8 indicates aptness/ correctness of the model and the $\mathrm{R}^{2}$ value less than 0.8 usually indicate an insufficiently precise description of the experimental data (Teklu and Lema, 2015). In this study, the coefficient of determination $\left(\mathrm{R}^{2}\right)$, which was found to be $0.9766,0.9543$ and 0.7869 respectively for moisture, salt, and total phenol content indicates that respectively $97.66,95.43$ and $78.69 \%$ of the variability in the response can be explained by these respective models. This shows that the equations (1 and 2) are suitable models to describe the response of the experiment. However, a large value of $\mathrm{R}^{2}$ does not always imply that the regression model is a good one, because the value of $\mathrm{R}^{2}$ always increases with the addition of a new variable to the model, regardless of whether additional variable is statistically significant or not (Onsekizoglu et al., 2010). Thus, it is preferred to use the adjusted- $\mathrm{R}^{2}$ to evaluate the model adequacy since it is adjusted for the number of terms in the model, that is, the number of factors. The adjusted- $\mathrm{R}^{2}$ should be over 0.9 indicating a high degree of correlation between the observed and predicted values (Shahabadi and Reyhani, 2014). In this study, the value of adjusted determination coefficient (Adj- $\mathrm{R}^{2}$ ) which was found to be 0.9445 , 0.9035 and 0.6885 respectively for moisture, salt, and total phenol content indicates a high significance of the model 1 and 2, but not for the model 3, which shows that the regression model explained the process well. So, it can be seen in Figure 3 (a) and Figure 3 (b) that values of moisture and salt content predicted by the model 1 and 2 are almost perfectly adjusted to the right. Predicted $-\mathrm{R}^{2}$ measures the amount of variation in new data explained by the model. Generally, a number closer to 1 is preferred (Onsekizoglu et al., 2010). The Predicted $\mathrm{R}^{2}$ was $0.7693,0.5792$ and 0.3364 respectively for moisture, salt, and total phenol content.

\subsection{Effects of model factors and their interaction on each response}

These results can be graphically discussed in the Pareto Chart (Figure 2), which displays the magnitudes of the effects from the results obtained. The effects are sorted from largest to smallest and all factors which are assigned by the sign $(+)$ or (-) have a positive or negative effect, respectively in the corresponding response. 

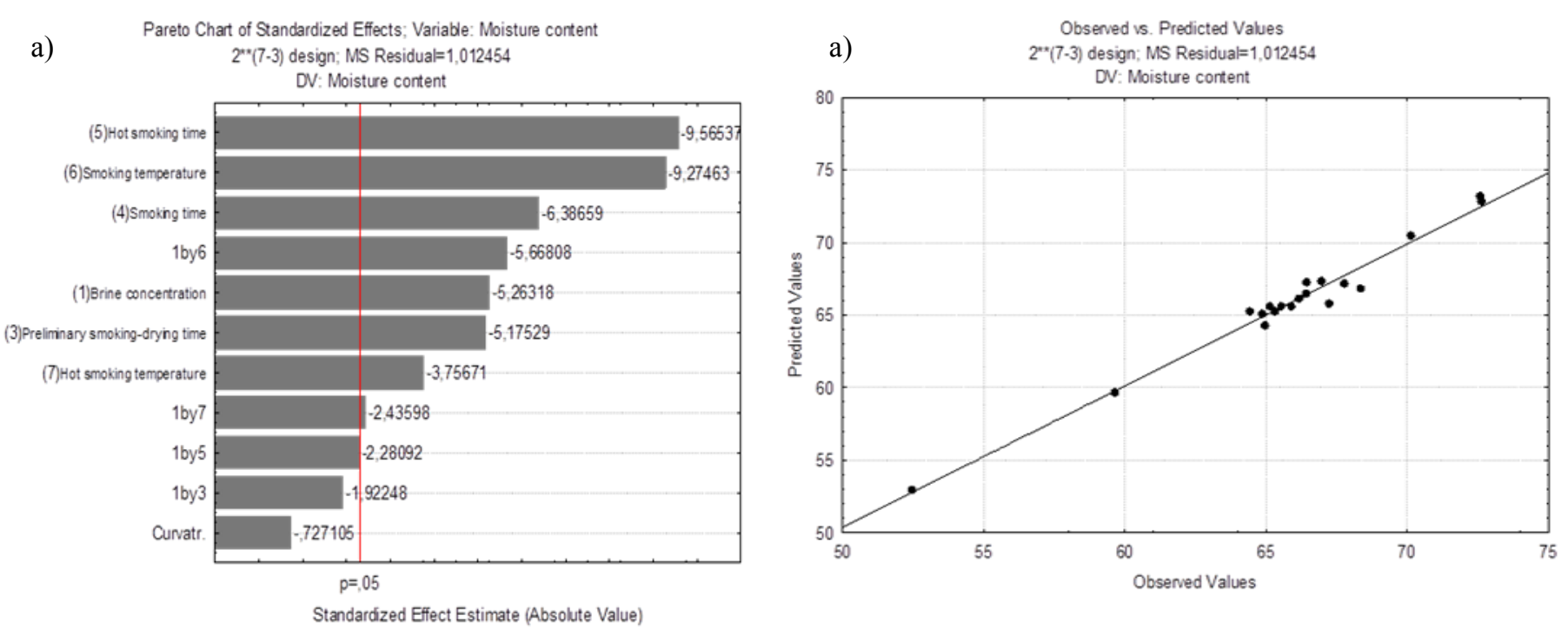

b)

Pareto Chart of Standardized Effects; Variable: Salt content 2**(7-3) design; MS Residual=, 1917181 DV: Salt content

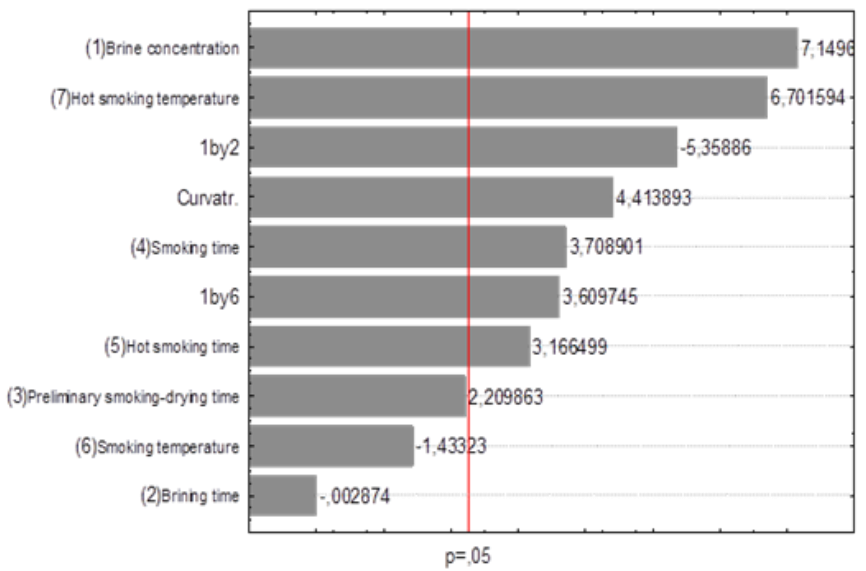

Standardized Effect Estimate (Absolute Value)
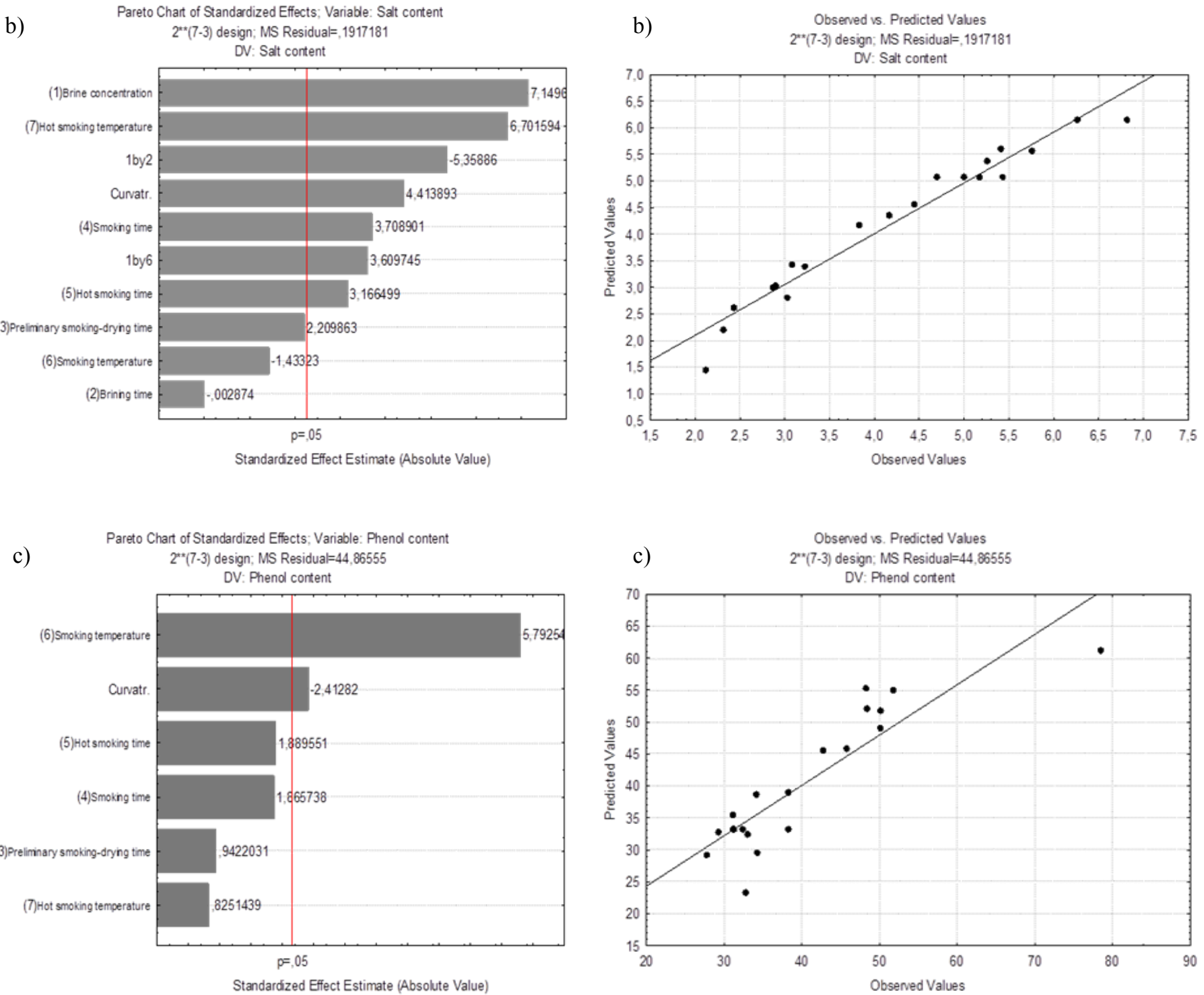

Figure 2. Pareto's chart of standardized effects for variables using the responses: (a) moisture content; (b) salt content; (c) phenol content.

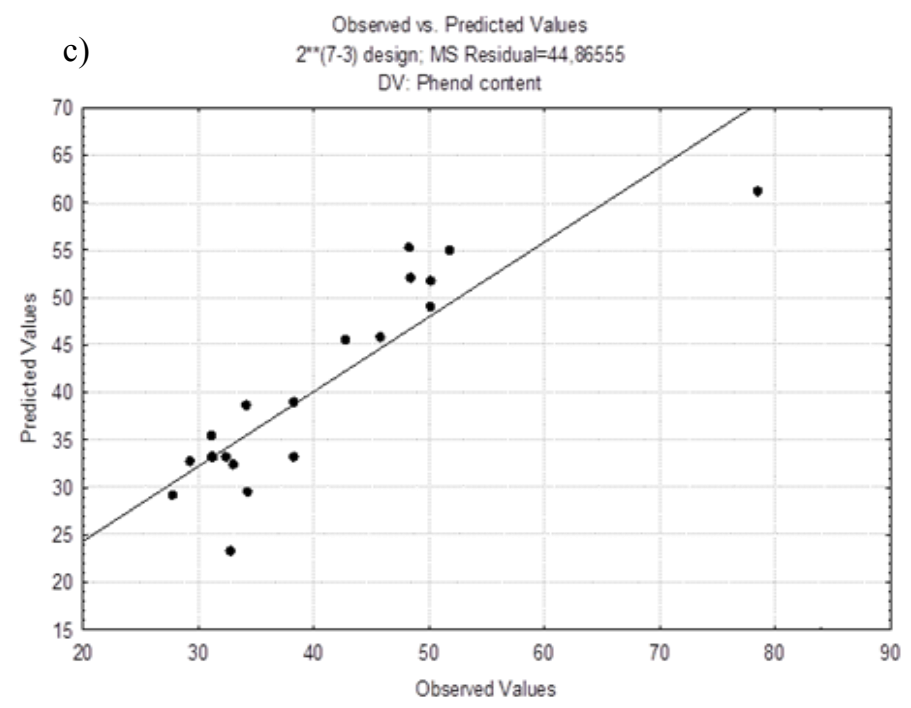

Figure 3. Comparison plot between experimental values and predicted values of; (a) moisture content; (b) salt content; (c) phenol content, using Equation 1, 2 and 3, respectively. 
Fitted Surface; Variable: Moisture content $2^{* *}(7-3)$ design; MS Residual=1,012454 DV: Moisture content

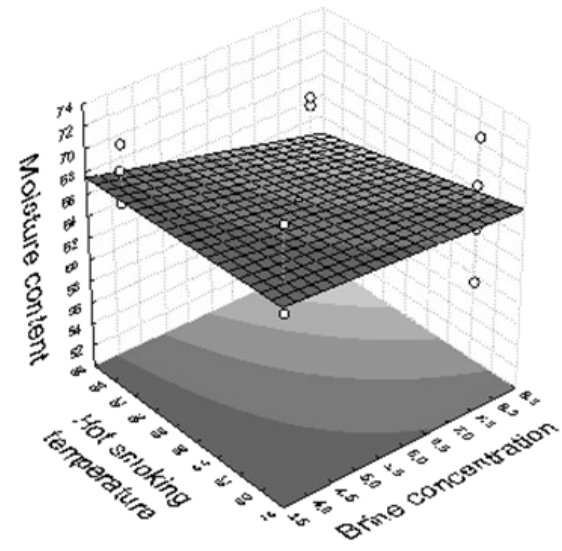

c) Fitted Surface; Variable: Salt content 2**(7-3) design; MS Residual=, 1917181 DV: Salt content

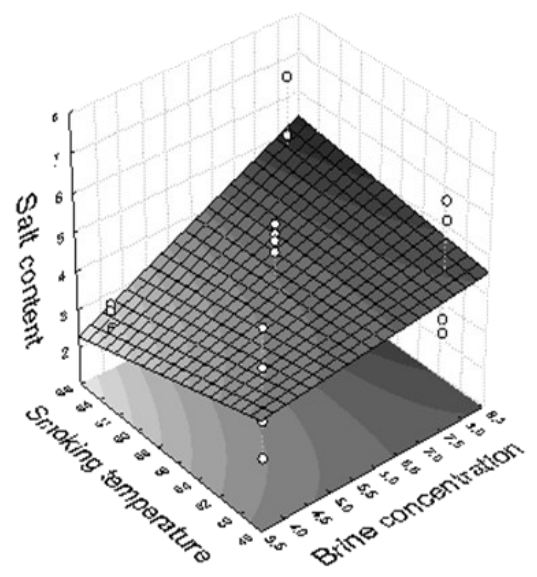

b)

Fitted Surface; Variable: Moisture content $2^{\star *}(7-3)$ design; MS Residual $=1,012454$ DV: Moisture content
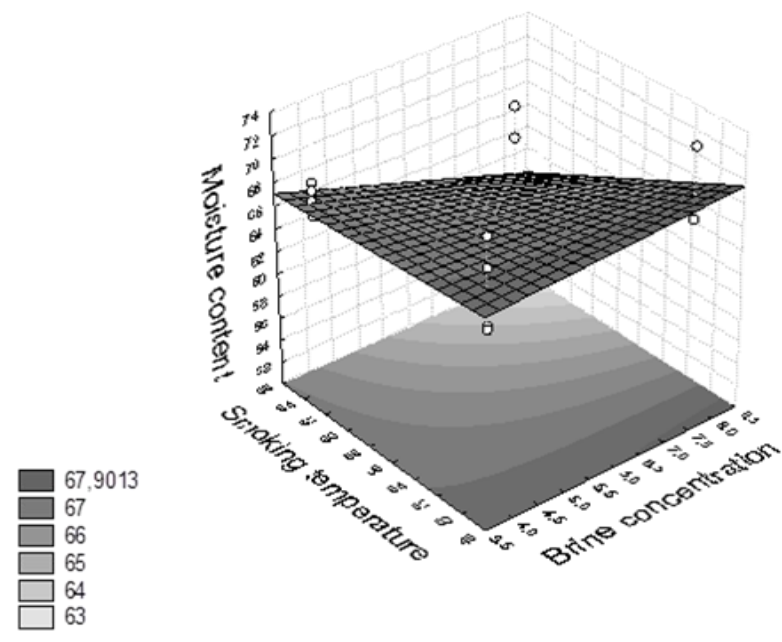

d) Fitted Surface; Variable: Salt content
$2^{* \star}(7-3)$ design; MS Residual $=, 1917181$ DV: Salt content

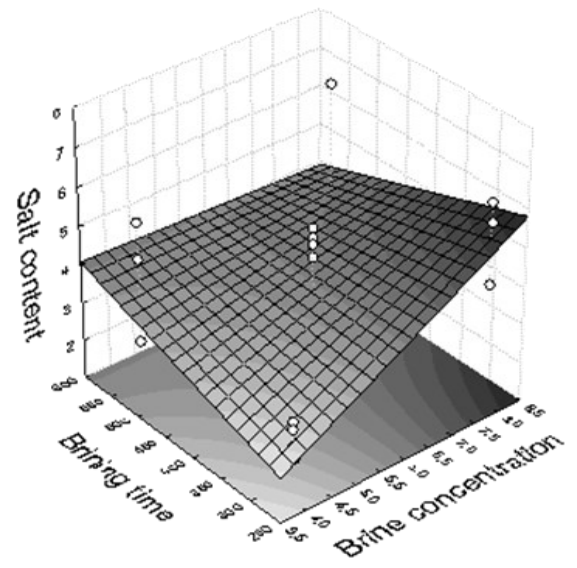

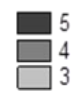

Figure 4. Responses surfaces and contour plots showing the effect of the interaction between; (a) brine concentration-hot smoking temperature on moisture content; (b) brine concentration-smoking temperature on moisture content; (c) brine concentration-smoking time on salt content; (d) brine concentration-brining time on salt content

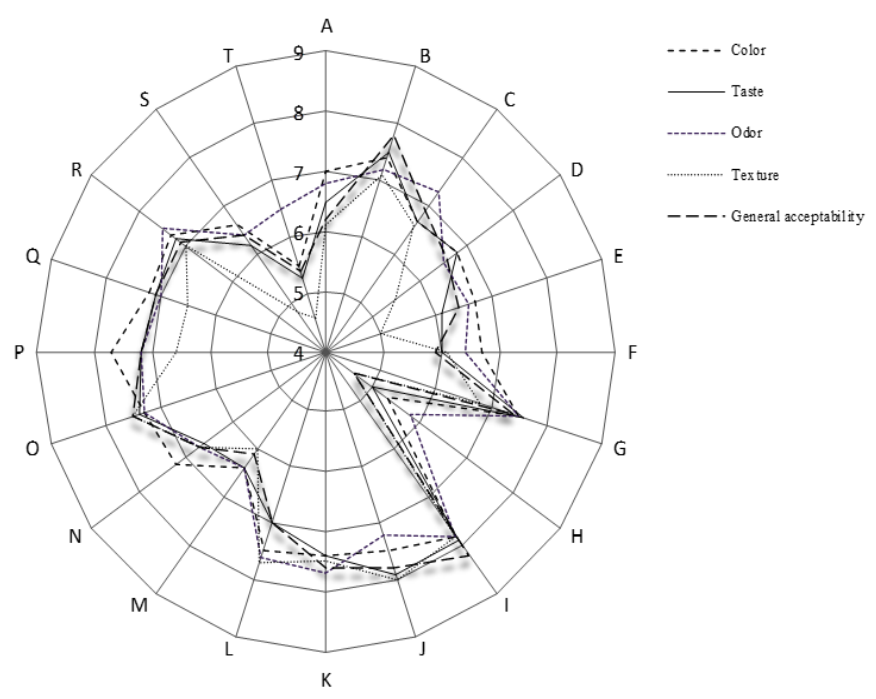

Figure 5. Radar chart of sensory evaluation of hot smoked Nile Perch as function of different smoking conditions
As can be seen in Figure 2(a), the increase in time and temperature in all smoking steps influenced negatively, in a statistically significant way, the water content of smoked fish fillet. The magnitudes of the effects, decreases in the order $\mathrm{X}_{5}, \mathrm{X}_{6}, \mathrm{X}_{4}, \mathrm{X}_{1}, \mathrm{X}_{3}$ and $\mathrm{X}_{7}$, indicating that the hot smoking time $\left(\mathrm{X}_{5}\right)$ and smoking temperature $\left(\mathrm{X}_{6}\right)$ affected moisture content most strongly than the other factors. As reported by Aba and Ifannyi (2013) processing parameters (time, temperature) are the main contributors for a lower moisture content of smoked fish. Indeed, increasing the temperature increases the vapor tension of water so the dehydration of the fish, and thereby increases water loss during the smoking process.

Figure 2(b) reveals that the increase in brine concentration and hot smoking temperature influenced positively, the salt content of smoked fish fillet. 
The magnitude of the effects on the salt content is higher for $\mathrm{X}_{1}$, indicating that the brine concentration affected salt content of smoked fish more strongly than any other factor. That could be attributed to the fact that, during brining the uptake of salt by the muscle and the loss of water from it occurs simultaneously, due to the differences in the osmotic pressure between muscle cells and the brine (Gallart-Jornet et al., 2007).

Concerning the total phenol content (Figure 2(c)), the magnitudes of the effects on the total phenol content decreased in the order $\mathrm{X}_{6}, \mathrm{X}_{5}, \mathrm{X}_{4}, \mathrm{X}_{3}$ and $\mathrm{X}_{7}$. Accordingly, operating smoking temperature $\left(\mathrm{X}_{6}\right)$ affected positively, the total phenol content more strongly than did any of the other parameters. A study by Chan et al. (1975) concerning smoked mackerel, using smoke produced from moist hickory sawdust, showed that concentrations of phenolic compounds in fish muscle increased when temperature increased up to $75^{\circ} \mathrm{C}$ and then decreased as the product surface dried.

One of the main advantages of factorial design methodologies is their ability to reveal the interaction between the input parameters under study. The best way to visualize these interactions on the dependent variables is to draw 3D surface response plots with the contour plots of the model, which were done by varying two variables within the experimental range and holding the other constant (middle value). Figure 4(a-d) shows the $3 \mathrm{D}$ surface plots of all the significant interaction effects confirmed by ANOVA. Figure $4(\mathrm{a}, \mathrm{b})$ shows the 3D surface plot of moisture content at varying temperature and brine concentration. From these figures, it can be observed that water content in smoked Nile Perch.

decreased with the increase of both brine concentration $\left(\mathrm{X}_{1}\right)$-smoking temperature $\left(\mathrm{X}_{6}\right)$ and brine concentration $\left(\mathrm{X}_{1}\right)$ - hot smoking temperature $\left(\mathrm{X}_{7}\right)$. For example, in Figure 4(b), at a lower smoking temperature of $50^{\circ} \mathrm{C}$ and lower brine concentration of $4 \%$, the moisture content was about $68 \%$. Whereas at a higher smoking temperature of $65^{\circ} \mathrm{C}$ and higher brine concentration of $8 \%$, the moisture content decreased to $60 \%$. On the other hand, the salt concentration of smoked fish increased with brine concentration and temperature to reach $4.75 \%$ and $5.5 \%$ at $50{ }^{\circ} \mathrm{C}$ and $65^{\circ} \mathrm{C}$ respectively (Figure $4 \mathrm{c}$ ). This could be due to the fact that the increase of temperature led to dehydration of the product linked to water evaporation, which resulted in an increase in the $\mathrm{NaCl}$ concentration per unit weight of product flesh. Figure $4 \mathrm{~d}$ shows the effect of brine concentration and brining time on the salt content.
This figure shows that at a low level of brine concentration, an increase in brining time increases salt content in smoked flesh fillet. On the contrary, at a high level of brine concentration, an increase in brining time decreases salt content. In fact, in many foodstuffs, the brining process generally led to salt gain and water loss. Nevertheless, Graiver et al. (2006) found that in the flesh, water movement (co- or counter-current) depended on the $\mathrm{NaCl}$ concentration of the brine solution. At very long contact times, that is, under equilibrium conditions, flesh treated with increasing concentrations of $\mathrm{NaCl}$ showed important modifications. For $\mathrm{NaCl}$ concentrations in the solution ranging between 5 to 200 $\mathrm{g} / \mathrm{L}$ the tissue gained water and incorporated high amount of solutes ("salting in"). Salt has, in fact, been shown to cause a significant displacement of water from the outside to the inside of the myofibrillar matrix (Bertram et al., 2001). According to Cheng and Sun (2008), an increase in water holding capacity and hydration in salted muscle fibers in low brine concentration are generally attributed to enhanced electrostatic repulsion between myofibrillar filaments. They suggested that $\mathrm{Cl}^{-}$ions bound to the filaments and increased the electrostatic repulsive force between them, the protein structure matrix unfolded and the swelling occurred causing the filament lattices to expand for water entrapment. The maximum water uptake is generally observed for $\mathrm{NaCl}$ concentrations ranging between 7 and $10 \%$ which is the consequence for a high weight gain as reported by Graiver et al. (2006). This phenomenon could be the reason of an apparent decrease in the salt concentration in the salted Nile perch fish fillets at $8 \%$ brine.

\subsection{Protein content}

In Table 5, the protein content of smoked Nile Perch ranged from 17.96 to $34.34 \%$ with sample D having the lowest value while sample $\mathrm{L}$ had the highest value. These lowest and highest values are significantly different from other treatments $(\mathrm{P}<0.05)$. The lowest $(52.44 \%)$ or highest $(72.65 \%)$ moisture content recorded respectively for sample $\mathrm{L}$ and sample D contributes to the highest or lowest crude protein value. Generally, after hot smoking, the protein content of the fillet will be higher due to increasing dry matter content per unit weight. This is mainly due to the removal of water during the smoking process (Steffens, 2006). In support of present findings, Jittinandana et al. (2002); Koral et al. (2010) have reported the protein content of 27.42 and $20.55 \%$ in hot smoked Oncorhynchus mykiss and hot smoked Sarda sardas respectively. However, Adeyemi 


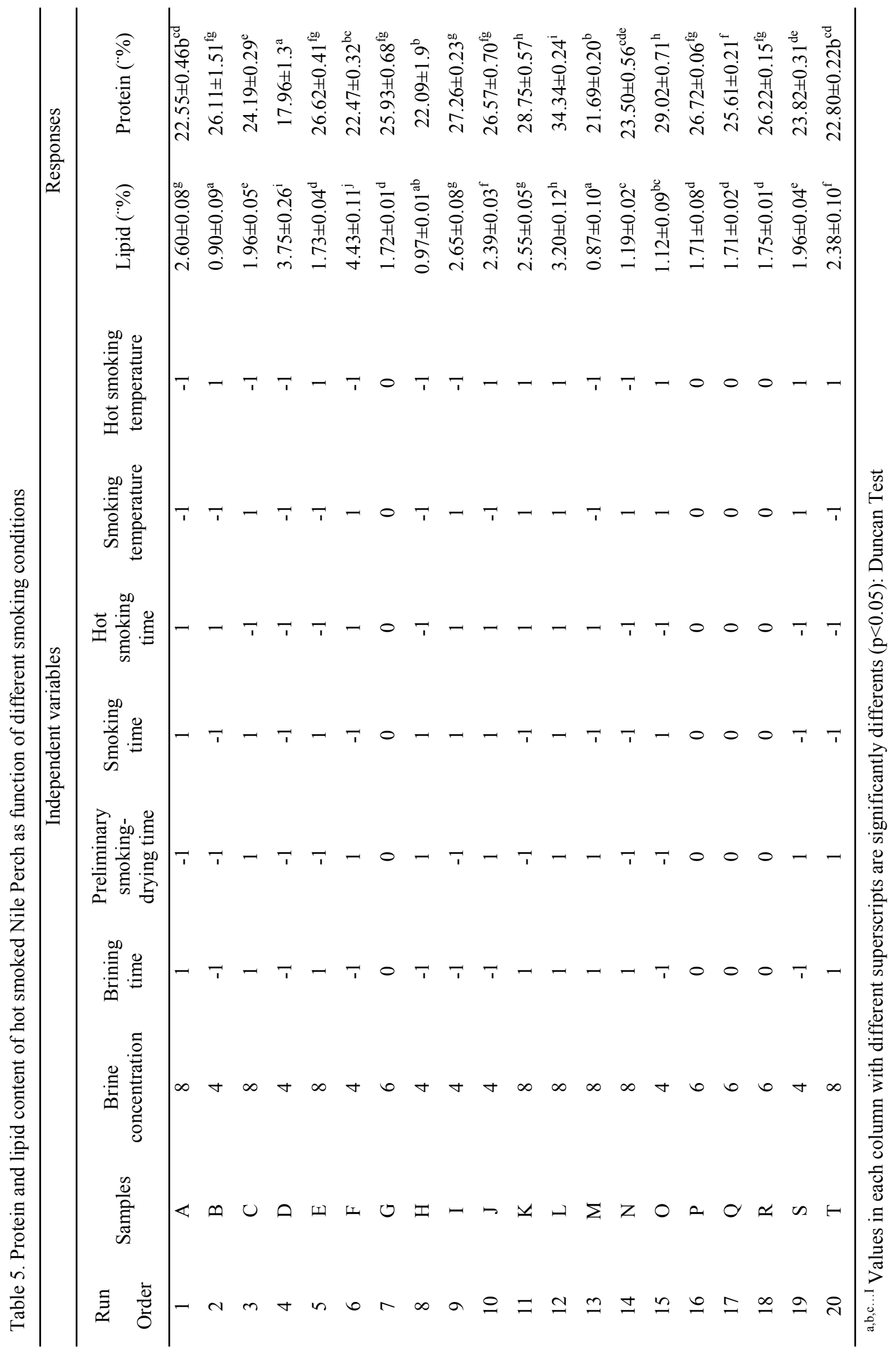


et al. (2013) have reported a high protein content of $55.57 \%$ in hot smoked Trachurus trachurus.

\subsection{Fat content}

The fat content of the smoked fish fillet ranged between $0.87 \%$ (sample $\mathrm{M}$ ) and $4.43 \%$ (sample F) (Table $5)$. Significant $(p<0.05)$ differences were observed in the fat content between sample $\mathrm{F}$ and all the other samples. It is also observed that sample L, despite its lowest water content, had a lipid content of $3.2 \%$, which was significantly lower $(p<0.05)$ than that of sample $F$ which had undergone less severe processing. This could be due to exudation of fat in smoked fillets at high temperature, resulting in low lipid content. In addition, oxidation during salting and smoking may also occur (Goulas and Kontominas, 2005; Guizani et al., 2014). Similar results $(0.7 \%$ to $2.0 \%)$ has been shown by Kabahenda et al. (2011) in hot smoked juvenile perch.

\subsection{Sensory evaluation}

Results of sensory evaluation based on a 9-point hedonic scale of smoked Nile Perch fish fillets are shown in Figure 5. In general, the average score of general acceptability, color, odor, texture and taste of the samples are significantly different $(p<0.05)$ and were between "neither like nor dislike 5" to "like very much 8 " in 9-point hedonic scale for taste, color, texture and general acceptability except for odor that was between "like slightly 6" to "like very much 8" in 9-point hedonic scale. In general, sample $\mathrm{H}$ received the lowest score with respect to odor, texture, taste, color and general acceptability probably due to it's both higher moisture and salt content. For the same sensory attributes (odor, texture, taste, color and general acceptability), sample I, with its firm texture and golden brown color, was most preferred by the panelist. The reasons for this high score are numerous but mainly come from its processing parameters. The process of color development in smoked fish begins with the carbonyls being absorbed into the surface. The carbonyls then react with amino groups in the fish and follow a similar path of reactions as in the Maillard browning reaction (Varlet, Prost and Serot, 2007). This group of reactions is enhanced as the temperature and dryness of the product are increased. The phenolic compounds play a prominent role in flavor development. Guaiacol is the phenolic primarily associated with smoke flavor, and syringol is the phenolic primarily associated with smoke aroma (Maga, 1988; Varlet, Prost and Serot, 2007). One of the most important quality characteristics of smoked fish flesh is its muscle texture. In hot-smoked foods, texture changes are mainly due to the denaturation of proteins by heat (Gill et al., 1992). In addition, the water content of smoked fish flesh strongly influences its texture, with lower water contents producing firmer products ( $\mathrm{Li}$ et al., 1998).

\section{Conclusion}

The evaluation of significant factors affecting the moisture, salt and total phenol content of smoked Nile Perch was performed using two-level fractional factorial design. In addition, the influence of different smoking conditions resulting from the experimental design was evaluated on the proximal composition and sensory characteristics of smoked Nile Perch. The results showed that all the factors (brine concentration, preliminary smoking-drying time, smoking time, hot smoking time, smoking temperature and hot smoking temperature) have a negative and significant effect on water content except the brining time. On the other hand, all the factors (brine concentration, preliminary smoking-drying time, smoking time, hot smoking time and hot smoking temperature) have a positive and significant effect on salt content except the brining time and smoking temperature. However, for total phenolic compound, only the smoking temperature has the most statistical significant effect in the chosen range. Different smoking conditions have a great influence on proximate composition content (Protein and lipid) and sensory quality (color, texture, odor, taste and overall acceptability) of the smoked fish fillet. The best smoking condition is, therefore, one that produces a final product with both best overall sensory acceptability and nutritional properties to a level that is beneficial to consumers, and a final product with good smoking criteria (moisture, salt, total phenol content). Thus, brining at $4 \% / 270 \mathrm{~min}$, drying at $30^{\circ} \mathrm{C} / 30 \mathrm{~min}$ and the smoked time/temperature cycles following: $30^{\circ}$ $\mathrm{C} / 120 \mathrm{~min} ; 50^{\circ} \mathrm{C} / 240 \mathrm{~min}$ and $80^{\circ} \mathrm{C} / 240 \mathrm{~min}$ is the best process condition for hot smoking Nile Perch (Lates niloticus).

\section{References}

Aba, I. P.and Ifannyi, N. (2013). Effects of smokedrying temperatures and time on physical and nutritional quality parameters of Tilapia (Oreochromis niloticus). International Journal of Fisheries and Aquaculture, 5(3), 29-34.

Adeyemi, O. T., Osilesi, O. O., Onajobi, F., Adebayo, O. 
and Afolayan, A. J. (2013). Stability study of smoked fish, horse mackerel (Trachurus trachurus) by different methods and storage at room temperature. African Journal of Biochemistry Research, 7(6), 98-106.

Arvanitoyannis, I. S. and Kotsanopoulos, K. V. (2012). Smoking of Fish and Seafood: History, Methods and Effects on Physical, Nutritional and Microbiological Properties. Food and Bioprocess Technology, 5(3), 831-853.

Association of Official Analytical Chemists. (2000). Official methods of analysis of AOAC international. Gaithersburg. 17th ed. Washington DC: Association of Official Analytical Chemists.

Bertram, H. C., Karlsson, A. H., Rasmussen, M., Pedersen, O. D., Dønstrup, S. and Andersen, H. J. (2001). Origin of Multiexponential $T_{2}$ Relaxation in Muscle Myowater. Journal of Agricultural and Food Chemistry, 49(6), 30923100 .

Cardinal, M., Cornet, J., Serot, T. and Baron, R. (2006). Effects of the smoking process on odour characteristics of smoked herring and relationships with phenolic compound content. Food Chemistry, 96(1), 137-146.

Cardinal, M., Gunnlaugsdottir, H., Bjoernevik, M., Ouisse, A., Luc Vallet, J. and Leroi, F. (2004). Sensory characteristics of cold-smoked Atlantic salmon (Salmo salar) from European market and relationships with chemical, physical and microbiological measurements. Food Research International, 37(2), 181-193.

Cardinal, M., Knockaert, C., Torrissen, O., Sigurgisladottir, S., Mørkøre, T., Thomassen, M. and Luc Vallet, J. (2001). Relation of smoking parameters to the yield, colour and sensory quality of smoked Atlantic salmon (Salmo salar). Food Research International, 34(6), 537-550.

Chan, W. S., Toledo, R. T. and Deng, J. (1975). Effect of smokehouse temperature, humidity and air flow on smoke penetration into fish muscle. Journal of Food Science, 40, 240-243.

Cheng, Q. and Sun, D.-W. (2008). Factors Affecting the Water Holding Capacity of Red Meat Products: A Review of Recent Research Advances. Critical Reviews in Food Science and Nutrition, 48(2), 137-159.

Gallart-Jornet, L., Rustad, T., Barat, J. M., Fito, P. and Escriche, I. (2007). Effect of super chilled storage on the freshness and salting behaviour of
Atlantic salmon (Salmo salar) fillets. Food Chemistry, 103(4), 1268-1281.

Gill, T. A., Chan, J. K., Phonchareon, K. F. and Paulson, A. T. (1992). Effect of salt concentration and temperature on heat-induced aggregation and gelation of fish myosin. Food Research International, 25, 333-341.

Goulas, A. E. and Kontominas, M. G. (2005). Effect of salting and smoking-method on the keeping quality of chub mackerel (Scomber japonicus): biochemical and sensory attributes. Food Chemistry, 93(3), 511-520.

Graiver, N., Pinotti, A., Califano, A. and Zaritzky, N. 2006. Diffusion of sodium chloride in pork tissue. Journal of Food Engineering, 77(4), 910918.

Guizani, N., Rahman, M. S., Al-Ruzeiqi, M. H., AlSabahi, J. N. and Sureshchandran, S. (2014). Effects of brine concentration on lipid oxidation and fatty acids profile of hot smoked tuna (Thunnus albacares) stored at refrigerated temperature. Journal of Food Science and Technology, 51(3), 577-582.

Hilderbrand, J. K. (1992). Fish smoking procedures for forced convection smokehouses. Extension Service Grant Program, Hatfield Marine Science Center. Special report No. 887, p. 41. Newport, Oregon: Oregon State University.

Jittinandana, S., Kenney, P. B., Slider, S. D. and Kiser, R. A. (2002). Effect of brine concentration and brining time on quality of smoked rainbow trout fillets. Journal of Food Science, 67(6), 20952099.

Kabahenda, M. K., Amega, R., Okalany, E., Husken, S. M. C. and Heck, S. (2011). Protein and micronutrient composition of low-value fish products commonly marketed in the Lake Victoria region. World Journal of Agricultural Sciences, 7(5), 521-526.

Karl, H., Äkesson, G., Etienne, M., Huidobro, A., Luten, J., Mendes, R. and Oehlenschläger, J. (2002). WEFTA Interlaboratory Comparison on Salt Determination in Fishery Products. Journal of Aquatic Food Product Technology, 11(3-4), 215 -228 .

Kjällstrand, J. and Petersson, G. (2001). Phenolic antioxidants in alder smoke during industrial meat curing. Food Chemistry, 74(1), 85-89.

Knockaert, C. (2002). Le fumage du poisson. 7th Ed. France: Ifremer, Editions Quae. 
Koral, S., Köse, S. and Tufan, B. (2010). The Effect of Storage Temperature on the Chemical and Sensorial Quality of Hot Smoked Atlantic Bonito (Sarda Sarda, Bloch, 1838) Packed in Aluminium Foil. Turkish Journal of Fisheries and Aquatic Sciences, 10(4), 439-443.

Li, R., Carpenter, J. A. and Cheney, R. (1998). Sensory and instrumental properties of smoked sausage made with mechanically separated poultry (MSP) meat and wheat protein. Journal of Food Science, 63(5), 923-929.

Maga, J. A. (1988). Smoke in food processing. Boca Raton : CRC Press

Marc, C., Kaakeh, R. and Mbofung, C. M. F. (1998). Effect of salting and smoking method on the stability of lipid and microbiological quality of Nile perch (Lates niloticus). Journal of Food Quality, 21(6), 517-528.

Montgomery, D. C. (2013). Design and analysis of experiments. 8th Ed. Hoboken, NJ: John Wiley and Sons, Inc.

Onsekizoglu, P., Savas Bahceci, K. and Acar, J. (2010). The use of factorial design for modeling membrane distillation. Journal of Membrane Science, 349(1-2), 225-230.

Poste, L. M., Mackie, D. A., Butler, G. and Elizabeth, L. (1991). Laboratory methods for sensory analysis of food. 1st Ed. Ottawa, Canada: Canada Communication Group, Pub. Centre.

Pszczola, D. E. (1995). Tour highlights production and uses of smoke-based flavors. Food Technology (USA), 49(1), 70-74

Rahman, S. (2007). Handbook of food preservation. $2^{\text {nd }}$ ed. Boca Raton: CRC Press.

Rora, A. M. B., Monfort, M. C. and Espe, M. (2004). Effects of country of origin on consumer preference of smoked salmon collected in a French hypermarket. Journal of Aquatic Food Product Technology, 13(1), 69-85.

Shahabadi, S. M. S. and Reyhani, A. (2014). Optimization of operating conditions in ultrafiltration process for produced water treatment via the full factorial design methodology. Separation and Purification Technology, 132, 50-61.

Steffens, W. (2006). Freshwater fish-wholesome foodstuffs. Bulgarian Journal of Agricultural Science, 12(2), 320.

Teklu, D. and Lema, A. (2015). Optimization of Time and Temperature for Smoking of Nile Tilapia for a Better Preservation of Protein and Gross Energy Value. Journal of Nutrition and Food Sciences, 5(1), 1-9.

Varlet, V., Prost, C. and Serot, T. (2007). New procedure for the study of odour representativeness of aromatic extracts from smoked salmon. Food Chemistry, 100(2), 820-829.

Varlet, V., Serot, T., Knockaert, C., Cornet, J., Cardinal, M., Monteau, F., Le Bizec, B. and Prost, C. (2007). Organoleptic characterization and PAH content of salmon (Salmo salar) fillets smoked according to four industrial smoking techniques. Journal of the Science of Food and Agriculture, 87(5), 847-854.

Werimo, K. (1996). Nile perch oil characteristics, composition and use. FAO Expert Consultation on Fish Technology in Africa. Vol. 6. Rome: FAO 